\title{
Economy Clustering as Efficiency Increase for Resource Usage in Key Areas of Sustainable Social and Economic Development in Kuzbass
}

\author{
Evdokiya Kulpina $^{1 *}$, Sergey Bereznev ${ }^{1}$, Natalya Golofastova ${ }^{1}$, and Alina Muromtseva ${ }^{1}$ \\ ${ }^{1}$ T.F. Gorbachev Kuzbass State Technical University, Vessenya 28 St., Kemerovo, Russia
}

\begin{abstract}
This article deals with Kuzbass industry modernization for efficient resource usage in key areas of sustainable social and economic region development. The modernization is considered as sustainable development and is connected with the structure and function change of the production system as a result of innovation implementation under the influence of the managing entity. The industrial cluster "Integrated processing of coal and industrial wastes" is considered to be the most significant one in cluster policy strategy in Kuzbass. Its purpose is to produce import-substituting coal and chemical products and related materials using the latest technologies for the deep processing of coal and industrial wastes.
\end{abstract}

\section{Introduction}

Kuzbass industry modernization must meet the requirements of sustainable innovative development according to the main provisions of the Strategy for Sustainable Development of the Russian Federation, the Strategy for Social and Economic Development of Kemerovo Region for the period up to 2035 and the Long-Term Development Program for Russian coal industry for the period up to 2030.

The sustainable development concept goes to universality and has a comprehensive interdisciplinary system of knowledge which considers the trends of natural evolution inextricably, the stages of technosphere development and the social and political processes of progressive civilization formation on the planet [3].

The approach analysis, presented in literature, shows that the concept of "sustainable development" is constantly being specified; it is in the process of developing. But the essence of sustainable development, firstly, does not rely on economic growth, and secondly, it is not separated from the improvement of the whole complex of technical and ecological and social factors of social production. Such processes as economic growth, modernization and economic society development are interconnected in this sustainable development.

\footnotetext{
${ }^{*}$ Corresponding author: kee.eomp@,kuzstu.ru
} 
The modernization considered in the context of sustainable development is connected with the structure and functions change of the production system as a result of innovation implementation under the influence of the managing entity.

\section{Results and Discussion}

The significant role has been assigned to cluster associations of business entities in achieving the goals and priorities of innovative development for recent years; as well as interaction with public and private partnership in the issues of territorial and spatial regions development with using cluster forms in the policies of social and economic development at the federal and regional levels [1].

The English term "cluster" means "grow together." The important point in the industrial cluster theory and practice concludes that the competitiveness of such production associations is provided by the presence of four factors: the development of the institutional environment, including ranking institutions; conditions for the rational use of resource potential - natural resources, labor resources, scientific and technical potential, market account requirements; highly connectedness connected with other forms operating in the market [2].

At present there is the meaning that "... clusters have become a consolidating force to achieve production efficiency and competitiveness increase in the context of globalization ..." Over the past 10 years the number of firms and employees involved in cluster associations has increased in most European countries on the background of cyclical and geopolitical problems [3]. It is also known that cluster associations can serve as an effective mechanism for attracting foreign direct investment to regions; and as well as the inclusion of the Russian Federation regional constituent entities into interregional and intercountry production chains of value creation, raw materials processing degree increase, economy diversification and the assembly plants localization increase on the new technical and technological base.

The innovation activity indicators presented in the table 1 and the analysis of statistical data (Form 10-T) of economic activity innovation structure and production complexes reflect a noticeable revival of the forms and methods of innovation activity in the Kuzbass business environment for recent years.

Thus, the number of innovations of all economic activity types was 46 in 2016, but in 2017 there were 78 . The number of organizations implementing technological innovations increased from 23 to 43 , including the field of industrial production from 17 to 37 . In our opinion, leadership is noted as a positive trend in the field of regional innovation activity. We analyzed innovation activities more than in 10 types of enterprises and manufactures. The manufacturing sector accounts for $63 \%$ in the total amount of all activity types in 2015 2017.

Table 1. Innovation activity indicators in 2013-2017.

\begin{tabular}{|l|l|l|l|l|l|}
\hline Innovation activity indicators & $\mathbf{2 0 1 3}$ & $\mathbf{2 0 1 4}$ & $\mathbf{2 0 1 5}$ & $\mathbf{2 0 1 6}$ & $\mathbf{2 0 1 7}$ \\
\hline $\begin{array}{l}\text { 1. Expenses for innovative technological, } \\
\text { marketing and organizational innovations, total, } \\
\text { mln. rub. }\end{array}$ & 6675 & 1207 & 3939 & 2573 & 3320 \\
\hline including & & & & & \\
\hline expenses for technological innovations, mln. rub. & 6662 & 1184 & 3900 & 2557 & 3314 \\
\hline out of them & & & & & \\
\hline $\begin{array}{l}\text { acquisition of machinery and equipment related } \\
\text { to technological innovation, mln. rub. }\end{array}$ & 2227 & 634.6 & 3737 & 2324 & 2312 \\
\hline $\begin{array}{l}\text { 2. The share of organizations implementing } \\
\text { technological innovations in the total number of }\end{array}$ & 3.9 & 5.3 & 3.3 & 2.6 & 5.4 \\
\hline
\end{tabular}




\begin{tabular}{|l|l|l|l|l|l|}
\hline surveyed,\% & & & & & \\
\hline $\begin{array}{l}\text { 3. Domestic current expenses on Research and } \\
\text { Development, mln. rub. }\end{array}$ & 1103 & 1414,8 & 1438.9 & 1583.6 & 2206.6 \\
\hline out of them & & & & & \\
\hline $\begin{array}{l}\text { in priority areas for the development of science, } \\
\text { engineering and technology * }\end{array}$ & & 319.8 & 772.3 & 847.5 & 1435.8 \\
\hline $\begin{array}{l}\text { 4. The share of innovative goods and services in } \\
\text { the total export of industrial production, } \%\end{array}$ & 0.2 & 2.6 & 2.9 & 2.1 & 1.7 \\
\hline
\end{tabular}

The expenses for technological innovations as a part of investments in non-financial assets, as well as investments in Research and Development, make up a small share approximately $2.6 \%$ and $0.8 \%$. The effectiveness of innovation activity in comparison with the average Russian indicators and the regions of the Siberian Federal District is low [Table 2].

Table 2. Innovation activity indicators in industrial production in particular regions of Russia.

\begin{tabular}{|l|l|l|l|l|l|}
\hline Indicators & Russia & $\begin{array}{l}\text { Krasnoyarsk } \\
\text { region }\end{array}$ & $\begin{array}{l}\text { Kemerovo } \\
\text { region }\end{array}$ & $\begin{array}{l}\text { Omsk } \\
\text { region }\end{array}$ & $\begin{array}{l}\text { Tomsk } \\
\text { region }\end{array}$ \\
\hline $\begin{array}{l}\text { The proportion of organizations } \\
\text { implementing technological } \\
\text { innovations, in the total number } \\
\text { of organizations }\end{array}$ & 0.363 & 0.407 & 0.22 & 0.352 & 0.385 \\
\hline $\begin{array}{l}\text { The proportion of organizations } \\
\text { implementing non- } \\
\text { technological innovations, in } \\
\text { the total number of } \\
\text { organizations for industrial } \\
\text { production organizations) }\end{array}$ & 0.233 & 0.263 & 0.15 & 0.243 & 0.306 \\
\hline $\begin{array}{l}\text { The proportion of organizations } \\
\text { having developed technological } \\
\text { innovations, in the total number } \\
\text { of organizations }\end{array}$ & 0.327 & 0.274 & 0.184 & 0.354 & 0.277 \\
\hline
\end{tabular}

The analysis and evaluation of innovative indicators, the dynamics of Kuzbass economy changes mentioned above actualize the multifactor process of producer clustering in the region.

We can say that Kuzbass economy, as an example, confirms a characteristic feature of Russian economy at present time; the noticeable trend of potential accumulation is not accompanied by a corresponding efficiency increase of production capital usage.

A retrospective analysis of the prerequisites for the cluster policy formation in Kuzbass showed that the accumulated problems (limitations and challenges) associated with the reproduction of regional factors of production and social conditions are a prerequisite. The initiatives of federal authorities in the areas of national economy clustering according to Decrees of the Government of the Russian Federation and Decrees of the President of the Russian Federation have become a stimulating factor [1].

The world experience in the formation of production clusters shows that nowadays there are two main models: liberal and conducting where the cluster policy is [4-10].

The cluster policy developing in Russia since the beginning of the 2000s with the priorities to innovative development and the managing model for all processes of its implementation has vague nature based on the national experience of the $90 \mathrm{~s}$. The process of intersectional industrial group formation was carried out with insufficient state participation, which transformed later into new relations of private property in sectoral and intersectoral holding companies. 
The vertically integrated industrial companies such as: EvrazHolding, SUEK, UTMK, SDS, Mechel, Kuzbassrazrezugol and a number of others create energy production cycles with low added value, the share of these enterprises in the total GRP is up to $70 \%$ in Kemerovo region. The structure of Kuzbass economy and its raw export-oriented nature determine the whole problem of regional economy clustering. Currently, the process of cluster policy formation in Kemerovo region is divided into three stages:

Stage 1 - preparatory, preceding the creation of clusters - 2007 - 2013;

Stage 2 - factor condition formation for the cluster development - 2014 - 2020;

Stage 3 - intensive innovative industry construction, processing facilities, sales market development - $2021-2035$.

At the beginning of 2019, there are four clusters (which are at different formation stages) in the Kemerovo region territory and economy:

1. Coal and chemical cluster;

2. Agro-industrial cluster;

3. Biomedical cluster;

4. Tourist cluster.

The industrial cluster "Comprehensive processing of coal and industrial wastes" is the most significant cluster policy strategy in Kuzbass. The purpose of its creation is the import-substituting coal and chemical product production and related materials with the newest technologies of deep coal and industrial waste processing usage [11 - 14]. The coal and chemical cluster program is one of the approved pilot programs of the innovative territorial clusters development of the Ministry of Economic Development of the Russian Federation. More than 26 thousand people are said to be involved in this cluster, with localization of small and medium-sized enterprises, SIEs, educational institutions, research institutes, investment and innovation infrastructure organizations in its production system.

The number of organizational and financial support activities for pilot innovative projects financed by the federal and regional budget was done according to the state program of Kemerovo region "Economic development and innovative Kuzbass economy in 2014-2020", as a part of the program "Implementation of activities provided by the investment project of the innovative territorial cluster development for coal and industrial wastes processing".

The analysis of formation and development activities of coal and chemical cluster and innovative industries of production waste processing approved by regional cluster strategy in $2007-2020$ is presented in the table 3.

Table 3. Cluster formation and development of deep coal and industrial waste processing in 2007 2020.

\begin{tabular}{|c|c|c|}
\hline Stage & $\begin{array}{c}\text { Cluster formation and development activities as a } \\
\text { part of a regional strategy }\end{array}$ & Progress mark \\
\hline \multirow{5}{*}{ 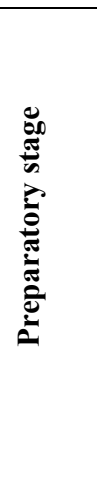 } & $\begin{array}{l}\text { 1. Priority selection of cluster policy, goal setting, strategy } \\
\text { choice of implementation tools. }\end{array}$ & \\
\hline & $\begin{array}{l}\text { 2. Stimulating conditions creation of processing facilities } \\
\text { development at newly commissioned coal mining } \\
\text { enterprises, attraction of public attention to problems and } \\
\text { tasks of potential investors in consideration of directions and } \\
\text { priorities of cluster policy. }\end{array}$ & Extremely insufficient \\
\hline & \multirow{2}{*}{$\begin{array}{l}\text { 3. Innovation and investment infrastructure preparation: } \\
\text { - construction of an industrial park; } \\
\text { - development of investment and potential participants in } \\
\text { cluster associations (industry enterprises and organizations, } \\
\text { universities ...). }\end{array}$} & Done \\
\hline & & $\begin{array}{l}\text { Partially at approval } \\
\text { level }\end{array}$ \\
\hline & 4. World experience analysis of economic systems & According to the results \\
\hline
\end{tabular}




\begin{tabular}{|c|c|c|}
\hline & clustering. & of 2018 , it continues \\
\hline & $\begin{array}{l}\text { 5. Regional investment legislation preparation, federal } \\
\text { cluster development programs participation. }\end{array}$ & $\begin{array}{l}\text { Mainly done within the } \\
\text { executive authority acts } \\
\text { (Kemerovo Region } \\
\text { Authority) }\end{array}$ \\
\hline & $\begin{array}{l}\text { 1. Regional program acceptance for the development of an } \\
\text { innovative and territorial cluster } \\
\text { - integrated coal and industrial wastes processing } \\
\text { 2020) }\end{array}$ & $\begin{array}{l}\text { Failed: programs } \\
\text { parameters are not } \\
\text { defined (organizational } \\
\text { and financial activities } \\
\text { are provided within the } \\
\text { subprogramme of the } \\
\text { state program } \\
\text { "Economic and } \\
\text { Development } \\
\text { Innovative Economy of } \\
\text { Kuzbass without } \\
\text { business participation") }\end{array}$ \\
\hline \multirow{8}{*}{ 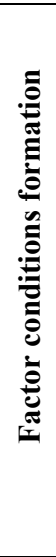 } & 2. Cluster development center creation. & Done \\
\hline & $\begin{array}{l}\text { 3. Key enterprise market research and new cluster members } \\
\text { involvement. }\end{array}$ & No information \\
\hline & $\begin{array}{l}\text { 4. Active product market research and partner and potential } \\
\text { customers searching for product clusters. Research results } \\
\text { popularization including international cooperation. }\end{array}$ & No information \\
\hline & $\begin{array}{l}\text { 3. Legislative conditions formation stimulating coal and } \\
\text { waste processing complexes construction. }\end{array}$ & Partially completed \\
\hline & $\begin{array}{l}\text { 4. Human resource capacity formation, university provision } \\
\text { with specialized laboratories, a selection of special projects, } \\
\text { changes and additions to educational programs. }\end{array}$ & Not done \\
\hline & 5. Engineering centers, design and engineering development. & No information \\
\hline & $\begin{array}{l}\text { 6. Pilot plants construction assistance for new technologies, } \\
\text { pilot unit creation, investment attraction. }\end{array}$ & No information \\
\hline & 7. Other investor introduction to a cluster & No information \\
\hline
\end{tabular}

\section{Conclusion}

The analysis of activities implementation for the formation and development of the planned innovation cluster as a part of leading coal mining and processing companies (SUEK-Ugol, SDS-Ugol, Koks), chemical production enterprises (Azot, Khimprom ) shows that this is the main direction of the entire cluster policy of Kuzbass. Thus, the cluster innovation policy implementation faces with a number of problems and limitations, including investment and organizational issues in relations and partnership between regional authorities and business.

Further cluster forms development for solving the strategic goal - regional economic system competitiveness increase and the new technological structure formation of Kuzbass economy needs to eliminate a complex of reasons that hinder the intensification of work on the formation of cluster associations and providing conditions for obtaining a synergistic effect from their activities. Clustering provides a wide range of resources and organizational efforts to solve the urgent economic development tasks and it allows using material and human resources more efficient. 


\section{References}

1. Ju. Janocko, M. Ryzhkova, T. Mamzina, S. Bereznev, E3S Web of Conferences, 105, 04022 (2019)

2. O. V. Buresh, A. V. Frolov, Proceedings of the International Conference, 1, 88 (2012)

3. S. V. Bereznev, M. K. Kumaneeva, M. A. Makin, Coal in the 21 st Century: Mining, Processing and Safety, 1 (2016)

4. F. Masahisa, P. Krugman and A. J. Venables, The spatial economy: Cities, regions, and international trade (MIT Press, Cambridge, 1999)

5. H. Mehlum, K. Moene, and R. Torvik, Economic Journal, 508, 1 (2006)

6. D. K. Carter, Remaking Post-Industrial Cities: Lessons from North America and Europe (Logan, New York, 2016)

7. C. J. Dawkins, Journal of Planning Literature, 2, 131 (2003)

8. G. Lux, Journal of Economics \& Management, 19, 16 (2015)

9. F. Masahisa, P. Krugman and A. J. Venables, The spatial economy: Cities, regions, and international trade (MIT Press, Cambridge, 1999)

10. P. Prisecaru, Knowledge Horizons - Economics, 2, 21 (2014)

11. V. G. Mikhailov, T. V. Galanina, Ya. S. Mikhailova, Gornyi Zhurnal, 4, 89-93 (2019)

12. V. G. Mikhailov, S. M. Bugrova, Ju. S. Yakunina, A. K. Muromtseva, Ya. S. Mikhailova, Ugol, 9, 106-111 (2019)

13. I. V. Kuznetsova, S. S. Timofeeva, IOP Conference Series: Earth and Environmental Science, 408, 012075 (2020)

14. S. S. Timofeeva, M. A. Murzin, IOP Conference Series: Earth and Environmental Science, 408, 012067 (2020) 